\title{
Studies on Comparative Behaviour of Performance Leading to Yield and integrated Management of Late Blight Disease of Potato in Allahabad Agro-Climate Condition
}

\author{
T. S. Mishra1 ${ }^{1}$ H. M. Singh ${ }^{2}$, Abhimanyu Chaturvedi ${ }^{3}$ and U. S. Mishra ${ }^{4 *}$ \\ ${ }^{1}$ Krishi Vigyan Kendra West Kameng Dirang Arunachal Pradesh, India \\ ${ }^{2}$ National Horticulture Research and Development Foundation, Patna (Bihar), India \\ ${ }^{3}$ Krishi Vigyan Kendra Tirap, Deomali, Arunachal Pradesh, India \\ ${ }^{4}$ Mahatma Gandhi Chitrakoot Gramodaya Vishwavidyalaya, Chitrakoot, Satna, M.P., India \\ *Corresponding author
}

\section{A B S T R A C T}

\begin{tabular}{|l|}
\hline Key w or d s \\
Potato, Variety, \\
Yield and disease \\
\hline Article Info \\
\hline $\begin{array}{l}\text { Accepted: } \\
\text { 15 May 2020 } \\
\text { Available Online: } \\
\text { 10 June } 2020\end{array}$ \\
\hline
\end{tabular}

The Field experiment was conducted in Allahabad order to evaluate the performance of different Potato (Solanum tuberosum L.) Varieties under the climatic conditions of Northern Plains of India during 2015-16 \& 2016-17. Carried out for two years to assess the morphology physiological behaviour of various potato varieties/strains/cultures under similar set of agro-climatic conditions. All the potato varieties/strains/cultures E-4486 ,JI5857, JI-1804, JI-1808, JG-224, JG-657,JE-808, JF-110,,JF-27, JF-547,JG-1134, Fr/B-10, JH-222, EM/H-1601,JF-4864,JF-5106, JF-4915,JH-49,JH-516,JI-5871,FR-B-4,FR-B4,FR/B-21,FR.B-105,G-2524,K.Sheetman,K.Chandramukhi, K. Bahar, K. Lalima, K. Badash, K. Jyoti, K. Alankar and K. Sinduri were replicated thrice in randomized block design. It is concluded that important information on different aspects of seed tuberssprouting, plant growth and development of parameters was gathered in all the treatments. All 32 varieties/strains/cultures grown in performance were found to express normal information for benefits of farmer. Findings of results were drawn on the basis of information gathered in observation recorded and data calculation for significance. Treatment JG-224, JH-222, FR/B-21, K. Chandramukhi, K. Lalima and K. Badshah were found promising. K. Badshah was found the best of all treatments and next best were $\mathrm{K}$. Bahar, K. Alankar and K. Sunder's.

\section{Introduction}

Potato (Solanum tuberosum L.) is a top ranking vegetable in India and other different countries (Chaudhary, 1967, 1972 and Chadha, 1998). It is one of the most important and unique crop among vegetables and in the sense it can supplement in a large number of ways (Kumar, 1972; Chandra et al., 1990; Singh, 1996). Potato has occupied a central place on tables as it provides all essential ingredients of balanced diet such as starch, protein, minerals and vitamins (Singh, 1959, 1996). During last two decades there has been 
a continuous increase in both area and production of potato in our country. It is grown in about several Lakhs hectares of land. Some of the Indian potato varieties, like, K. Chandramukhi, K. Sheetman and K Lokar are found suitable for export and can earn foreign exchange in substantial amount (Pushkarnath, 1964; Rai, 1984; Singh, 1992; Basu, 1996; Minhas et al., 2018). At present a large number of high yielding varieties and several hybrids have been developed by central potato Research Institute, Simla and are available for commercial cultivation in the country (ICAR Report, 1981). However, considerable controversy exists about potato varieties/strains regarding yield and several qualitative characters which are influenced by soil and environmental factors to a considerable extent. At this stage little is known for about the morphological and physiological factors which allow one variety to out-yield the other when both are grown under the similar set of agro-climatic conditions (Tiwari and Tiwari, 1975; Rai, 1986; Sud, 1996; Taule, 2010).

In fact yield and qualitative characters are the products of many physiological processes occurring in various plant parts (Moorly, 1978). They are also affected by environmental and agronomical factors (Pandita, 1971). Difference in inherent yield ability could arise from any one or more of the physiological processes, like net assimilation rate, translocation and utilization of photosynthetic (Palkar, 1956; Purohit et al., 1970; Murty, 1978). Identification and utilisation of these characters might help considerably in selection of suitable variety/strain/culture (Gupta and Saxena, 1976; Tripathi, 1985; Auhkamath, 1989; Naik, 1997).It is true that yield and dry matter are controlled by photosynthesis, while photosynthesis is affected by leaf area, leaf area index, leaf area ratio, chlorophyll content and other environmental factors (Pandita
1971; Gupta and Rai 1977; Collins, 1977, Singh, 1984; Gasti, 1994). In fact these factors limiting the total yield which may be due to the lack of development of leaf area, photosynthetic system and other environmental factors. In some varieties, the foliage amounts more than the dwarf growing varieties (Gangiger, 1952; Khanna and Pandita, 1986; Gasti, 1992).

In some varieties/strains the foliage growth is to excess which becomes luxury production of leaves. However, such high foliage may not be need but on the other hand it may be a needful on plant resources (Murlidharan and Amlraj, 1991; Kalir, 1990). It is now well known that potato tuber yield is directly related to growth parameters and the longevity of the leaves present during the tuber growth (Davis, 1969; Mc Culan, 1991; Hagy and Fangmelar, 2009).The variation in climatic conditions and environmental factors prevail in an area which affects the yield at varietal level. Not only a variety but disease factor like blights, sometimes, well grown crop expecting high yield may suffer and ultimately loss in yield due to the causes of burning foliage by the blights (Foxe, 1990; Randhawa, 1993). Sometimes crop is very well in the evening but it may reveal the opposite result only because of the disease during the night period (Mishra, 1996; I.P.C.C., 2007). Such sensitive to diseases and atmospheric conditions it is destroyed within a short period (Luthra et al., 2008). So the detailed study of varieties/strains/cultures is essential a particular region for its suitability for higher yield.

\section{Materials and Methods}

The present experiment entitled was carried out at Allahabad, Uttar Pradesh during 201516 and 2016-17. The research experiments were carried Performance and evaluation of potato (Solanum tuberosum L.) varieties in 
Northern Plains of India. Out in the farmers field where different fields of trials. Geographically located at about $20^{\circ} \mathrm{C} 28^{\prime} \mathrm{N}$ (latitude) and $80^{\circ} 24^{\prime} \mathrm{E}$ (longitude), about 135 meter above sea level. The climate is subtropical, semi arid with hot dry summer and severe cold winters. Total monthly distribution of rainfall, temperature and relative humidity during the period of investigations for both years was observed. In the present study experiments were carried out for two years to assess the morphology physiological behaviour of various potato varieties/strains/cultures under similar set of agro-climatic conditions. All the potato varieties/strains/cultures E-4486 ,JI-5857, JI1804, JI-1808, JG-224, JG-657,JE-808, JF110,JF-27，JF-547,JG-1134， Fr/B-10， JH222, EM/H-1601,JF-4864, JF-5106, JF4915,JH-49,JH-516,JI-5871,FR-B-4,FR-B-4, FR/B-21， FR.B-105,G-2524, K.Sheetman, K.Chandramukhi, K. Bahar, K. Lalima, K. Badash, K. Jyoti, K. Alankar and K. Sinduri were replicated thrice in randomized block design.

\section{Results and Discussion}

Present investigation on different varieties/strains/cultures was taken up at the farmer's field. These germplasm potato varieties/ strains/cultures were grown in previous year for general- preliminary observations regarding the different aspects of the potato crop in respect of its suitability for experiments. Present investigations on different aspects of potato varieties/ strains/cultures were carried out at Bioved Research Institute of Agriculture and Technology, Allahabad during 2015-16 and 2016-17. Experiments were laid out in randomized block design with three replication in fields having the manorial dose of $120 \mathrm{~kg}$ Nitrogen, $80 \mathrm{~kg} \mathrm{P}_{2} \mathrm{O}_{5}$ and $80 \mathrm{~kg}$ $\mathrm{K}_{2} \mathrm{O}$ per hectare was applied to the experimental plots. Experimental crop was grown as schedule data were presented in tables and also depicted in figures. The tubers of 32 varieties/strains/cultures revealed variable period for sprouting in all the treatments. Self tuber sprouting was found maximum 77.67 in Variety FR/B-21 during 2015-16 and in next year trial it was height 75.00 per cent in Variety Fr/B-10. The sprouting showed considerable variation which might be due to the internal potentiality of tubers and external soil conditions. Shoot growth was found variable in sprouting of tubers which was found to range from 4.73 to 8.40 shoots per plant in Variety E-4486 and Kufri Badshah and, K. Lalima during 201516 , respectively. Next year trial sprouts varied from 4.50 (E-4486) to 8.46 per plant $(\mathrm{k}$. Lalima) during 2016-17. Plant growth parameters were found to have considerable range of variation in different varieties/ strains/cultures taken as treatments in present investigations. The plant height found ranging from 44.37 to $78.43 \mathrm{~cm}$ in FR-B-4 to JI-5857 Variety during 2015-16 and in the next year it was varying from 47.20 to $80.30 \mathrm{~cm}$ in Variety JF-4915 to K. Sheetman during 201617, respectively. In vegetative growth behaviour leaf parameter was found an important factor in potato crops. Leaf growth was per plant was found variable in all the treatments of varieties/strains/cultures during both years of the investigations number of leaves growth was found to range from 67.33 to 89.00 per plant in variety $\mathrm{JH}-222$ to $\mathrm{K}$. Badshah during 2015-16, respectively. In the next year experiment it was found to vary from to 90.33 per plant in $\mathrm{K}$. Bahar, K. Lalima Varieties.

In potato varieties/strains/cultures length of leaf was also recorded an important factor in observations. Length of leaves was found to have considerable variations in different treatments. Leaf length variation was found during both years of the experiments. In first year trial leaf length varied from 18.37 to 
$24.31 \mathrm{~cm}$ leaf in JI-5871 to JF-27 and in second year experiment it ranged from 17.97 to $23.77 \mathrm{~cm}$ leaf in JI-5871 to JH-222, JF5106 Variety, respectively. Width of leaves was also found in considerable variability. The maximum with of leaf was found 15.97 and $15.40 \mathrm{~cm} /$ leaf in JF-547 and JF-27 treatments in 2015-16 and 2016-17, respectively. The minimum width of leaf was found 10.53 (E-4486) and 10.60 (E-4486) during 2015-16 and 2016-17, under physiological role both parameters are very important one in general and particular in potato. Potato tuber growth and development was found at the tip point of the staleness in all the varieties/strains/cultures. Stolen growth in number per plant was found variable in all the treatments. It was found to range from 17.33 (E-4486, JI 1808) to 24.00 per plant (k. Sinduri) and in next year trial it was 16.00 (E4486) to 26.00 per plant (K. Sinduri) during 2015-16 and 2016-17, respectively.

Stolen length was found in variability behaviour in its growth and development in different treatments. Stolen length varied from $7.60(\mathrm{JH}-222)$ to 13.53 on (E-4486) and 7.00 (JH-222) to $13.37 \mathrm{~cm} /$ stolen (K. Lalima) during 2015-16 and 2016-17, respectively. The maximum stolen length was followed $12.10 \mathrm{~cm}$ (K. Badshah), $12.00 \mathrm{~cm} \mathrm{(K}$. Lalima), $11.27 \mathrm{~cm}$ (K. Jyoti) and $11.20 \mathrm{~cm}(\mathrm{~K}$. Badshah), 11.13 (K. Bahar) during 2015-16 and 2016-17, respectively.

Stolen was found to have the potato tuber which indicated also to the maturity of shoots in plants. It was a stage at which reproducing growth was initiated. The emergence of the flower buds was found variable in different varieties/strains/cultures of potato in present investigations. The minimum number of days was found 93.11 and 93.47 in variety $\mathrm{JH}-222$ and JH-222 during 2015-16 and 2016-17, respectively. The maximum period of 110.86 and 110.76 days was observed for appearing reproductive growth in treatments $K$. Sheetman and G-2524 in first and second year of investigations, respectively.

The minimum period for opening of the reproductive bud was found 93.00 and 93.07 days in E-4486 treatment during 2015-16 and 2016-17, respectively. The appearance of reproductive growth indicated the maturity of vegetative growth of potato plants. Tuber production per plant in different treatments becomes the basis of tuber yield. The number of tubers was found to vary from 73.00 (E4486 ) to 15.57 per plant (K. Sinduri) in the experiments of 2015-16 and 2016-17, respectively. In general observations above ten tubers per plant were recorded in different treatments. Potato tubers growth and development led to its maturity which ultimately resulted in yield. In results of tuber maturity period was found variable from 95.23 and 114.00667 days in Fr/B-10 to JI5871 in first year of investigations. Similarly in second year trial the period of tubers maturity was also found variable in different treatments. The yield of potato tubers was considered the most important trait of the crop. Different treatments produced varying yield of tubers was found to range from 187.43 (JF-4864) to 413.90 quintiles per hectare during 2015-16. Similarly varying yield ranging from 214.47 to 331.99 quintals in FR/B-21 to JH-222 treatments was found in second year trial. Dry matter content after 75 days was found to range from $13.73(\mathrm{JH}-222)$ to 15.63 per cent (FR/B-21) and $13.80(\mathrm{JH}-$ $222)$ to 15.73 per cent (K. Badshah) during 2015-16 and 2016-17, respectively. The next best content of 15.33 (k. Badshah) and 15.47 per cent (JH-49) was found in first and second year experiments, respectively. In potato crop yield contributing factors were found mainly plant growth parameters along with nutrients. Applied to the crop, Plant height, shoot growth, leaves growth, development and production for normal yield of tubers. 
Table.1 Studies on comparative behaviour of performance leading to vegetative characters and integrated management of Late blight disease of Potato varieties/strains/cultures

\begin{tabular}{|c|c|c|c|c|c|c|c|c|c|c|c|c|c|c|}
\hline \multirow[t]{2}{*}{ Variety } & \multicolumn{2}{|c|}{$\begin{array}{l}\text { Potato Seed tuber } \\
\text { sprouting }(\%)\end{array}$} & \multicolumn{2}{|c|}{$\begin{array}{c}\text { Number of } \\
\text { shoots/ plant }\end{array}$} & \multicolumn{2}{|c|}{ Plant Height $(\mathrm{cm})$} & \multicolumn{2}{|c|}{$\begin{array}{c}\text { Number of } \\
\text { leaves/ plant }\end{array}$} & \multicolumn{2}{|c|}{$\begin{array}{l}\text { Length of leaf } \\
(\mathrm{cm})\end{array}$} & \multicolumn{2}{|c|}{ Width of leaf $(\mathrm{cm})$} & \multicolumn{2}{|c|}{$\begin{array}{c}\text { Number of } \\
\text { stolons/plant }\end{array}$} \\
\hline & 2015-16 & 2016-17 & $\begin{array}{c}2015- \\
16\end{array}$ & $\begin{array}{c}\text { 2016- } \\
17\end{array}$ & $\begin{array}{c}2015- \\
16\end{array}$ & $\begin{array}{c}\text { 2016- } \\
17\end{array}$ & $\begin{array}{l}2015- \\
16\end{array}$ & $\begin{array}{c}2016- \\
17\end{array}$ & $\begin{array}{c}2015- \\
16\end{array}$ & $\begin{array}{c}\text { 2016- } \\
17\end{array}$ & $\begin{array}{c}2015- \\
16\end{array}$ & 2016-17 & 2015-16 & 2016-17 \\
\hline E-4486 & 58.00 & 71.67 & 5.00 & 4.50 & 76.13 & 79.07 & 78.00 & 76.00 & 20.27 & 19.29 & 10.53 & 10.60 & 17.33 & 16.00 \\
\hline JI-5857 & 71.00 & 66.00 & 5.03 & 4.90 & 78.43 & 76.83 & 75.00 & 77.33 & 19.90 & 19.33 & 12.83 & 12.83 & 18.00 & 18.00 \\
\hline JI1804 & 53.00 & 59.33 & 5.70 & 5.37 & 71.40 & 75.43 & 74.00 & 77.33 & 21.51 & 21.33 & 14.40 & 14.30 & 19.00 & 20.00 \\
\hline JI1808 & 73.33 & 68.57 & 5.70 & 5.63 & 48.23 & 51.70 & 70.00 & 70.67 & 22.27 & 22.23 & 13.97 & 14.60 & 17.33 & 19.00 \\
\hline JG-224 & 66.67 & 64.00 & 5.67 & 5.47 & 45.50 & 49.60 & 72.00 & 68.33 & 23.20 & 23.19 & 14.53 & 14.83 & 18.00 & 18.00 \\
\hline JG-657 & 72.00 & 66.00 & 6.27 & 6.47 & 44.57 & 56.30 & 70.33 & 71.67 & 22.13 & 21.80 & 14.97 & 14.97 & 20.00 & 20.67 \\
\hline JE-808 & 66.33 & 70.67 & 6.23 & 6.37 & 53.00 & 52.30 & 72.33 & 72.67 & 22.77 & 22.83 & 15.23 & 14.20 & 21.00 & 20.67 \\
\hline JF-110 & 71.67 & 71.67 & 6.83 & 7.23 & 72.07 & 74.90 & 74.33 & 71.00 & 21.71 & 21.27 & 14.40 & 14.47 & 21.67 & 22.67 \\
\hline JF-27 & 54.33 & 60.67 & 4.73 & 5.70 & 73.73 & 72.03 & 72.67 & 71.33 & 24.31 & 23.03 & 15.37 & 15.40 & 22.00 & 22.00 \\
\hline JF-547 & 75.00 & 73.67 & 5.30 & 5.30 & 74.37 & 79.30 & 75.67 & 72.00 & 21.63 & 21.33 & 15.97 & 14.67 & 21.00 & 19.33 \\
\hline JG1334 & 71.67 & 73.00 & 5.40 & 5.10 & 77.87 & 80.17 & 76.00 & 73.67 & 22.43 & 22.17 & 12.60 & 12.23 & 20.67 & 20.00 \\
\hline FR/B-10 & 70.67 & 75.00 & 7.23 & 7.00 & 68.00 & 72.80 & 76.00 & 76.83 & 20.43 & 19.80 & 12.73 & 12.83 & 18.67 & 18.67 \\
\hline JH-222 & 68.33 & 74.67 & 7.17 & 6.67 & 75.00 & 80.30 & 75.67 & 78.00 & 23.51 & 23.77 & 12.13 & 12.10 & 18.00 & 20.00 \\
\hline EM/H-1601 & 69.67 & 72.67 & 6.13 & 6.23 & 74.30 & 72.83 & 82.67 & 81.67 & 21.17 & 21.31 & 11.60 & 11.73 & 22.00 & 21.00 \\
\hline JF-4864 & 66.00 & 73.33 & 6.50 & 6.43 & 51.43 & 76.70 & 79.00 & 79.67 & 23.27 & 22.37 & 11.30 & 12.30 & 21.33 & 19.67 \\
\hline JF-5106 & 46.33 & 72.33 & 6.97 & 6.27 & 74.77 & 74.90 & 76.33 & 81.00 & 22.83 & 23.77 & 10.90 & 11.10 & 19.83 & 20.00 \\
\hline JF-4915 & 62.33 & 72.67 & 7.23 & 6.97 & 49.50 & 47.20 & 67.33 & 71.67 & 21.53 & 22.03 & 12.14 & 12.30 & 21.00 & 18.00 \\
\hline JH-49 & 65.00 & 56.33 & 7.87 & 7.33 & 73.43 & 73.60 & 70.00 & 67.00 & 23.63 & 23.77 & 14.53 & 14.70 & 18.67 & 18.00 \\
\hline JH-516 & 65.67 & 49.00 & 6.97 & 6.63 & 74.40 & 73.47 & 74.00 & 73.67 & 22.20 & 21.53 & 13.13 & 13.31 & 20.00 & 20.00 \\
\hline JI-5871 & 71.00 & 62.33 & 6.57 & 6.17 & 61.90 & 79.03 & 74.33 & 80.33 & 18.37 & 17.97 & 11.30 & 11.41 & 19.33 & 18.67 \\
\hline FR-B-4 & 72.33 & 72.67 & 5.50 & 5.93 & 44.37 & 73.90 & 72.67 & 73.00 & 20.27 & 19.67 & 11.38 & 11.58 & 20.33 & 21.00 \\
\hline FR/B-21 & 60.00 & 64.67 & 5.13 & 5.47 & 51.23 & 59.67 & 70.33 & 70.33 & 19.89 & 19.56 & 12.65 & 12.36 & 23.00 & 22.00 \\
\hline FR/B-105 & 77.67 & 64.67 & 5.93 & 6.13 & 74.23 & 54.90 & 74.67 & 85.33 & 22.22 & 22.43 & 12.26 & 12.17 & 22.00 & 22.00 \\
\hline G-2524 & 66.67 & 66.67 & 6.27 & 6.47 & 72.03 & 74.50 & 79.00 & 84.00 & 21.50 & 22.12 & 22.10 & 22.47 & 21.00 & 21.00 \\
\hline K. Sheetman & 73.33 & 69.33 & 6.00 & 6.17 & 74.23 & 80.30 & 77.00 & 80.33 & 23.73 & 23.76 & 13.32 & 13.64 & 20.00 & 19.33 \\
\hline K. Chandramukhi & 74.00 & 71.67 & 6.90 & 6.50 & 69.07 & 79.27 & 70.33 & 69.33 & 22.16 & 22.43 & 12.73 & 12.53 & 19.33 & 20.00 \\
\hline K. Bahar & 70.67 & 71.67 & 8.40 & 8.30 & 74.20 & 70.60 & 88.33 & 90.33 & 21.23 & 21.41 & 12.65 & 12.33 & 20.67 & 20.00 \\
\hline K. Lalima & 67.67 & 67.67 & 8.37 & 8.60 & 75.37 & 76.80 & 86.00 & 90.33 & 18.32 & 18.76 & 11.72 & 11.55 & 18.00 & 20.67 \\
\hline K. Badshah & 69.00 & 70.00 & 8.40 & 8.43 & 74.37 & 54.87 & 89.00 & 88.33 & 23.23 & 23.15 & 13.17 & 12.79 & 19.00 & 20.00 \\
\hline K. Jyoti & 69.00 & 70.00 & 7.73 & 7.37 & 48.73 & 53.70 & 81.67 & 85.67 & 22.53 & 21.63 & 12.25 & 12.52 & 20.33 & 20.67 \\
\hline K. Alankar & 72.00 & 69.00 & 6.30 & 6.50 & 69.53 & 78.03 & 79.00 & 80.00 & 21.35 & 22.11 & 12.14 & 12.14 & 21.00 & 20.67 \\
\hline K. Sinduri & 69.00 & 69.33 & 7.30 & 7.27 & 62.57 & 75.40 & 88.67 & 80.00 & 18.37 & 18.85 & 11.26 & 11.28 & 24.00 & 26.00 \\
\hline C.D at $5 \%$ & 12.72 & 16.11 & 0.64 & 0.58 & 2.80 & 5.11 & 5.85 & 4.47 & 0.96 & 0.93 & 0.54 & 0.54 & 2.04 & 2.16 \\
\hline
\end{tabular}


Table.2 Studies on comparative behaviour of performance leading to yield characters and integrated management of Late blight disease of Potato varieties/strains/cultures

\begin{tabular}{|c|c|c|c|c|c|c|c|c|c|c|c|c|c|c|c|c|}
\hline \multirow[t]{2}{*}{ Variety } & \multicolumn{2}{|c|}{ Stolen length $(\mathrm{cm})$} & \multicolumn{2}{|c|}{$\begin{array}{l}\text { No. of days required for } \\
\text { bud growth }\end{array}$} & \multicolumn{2}{|c|}{$\begin{array}{l}\text { No. of days for } \\
\text { I }^{\text {st bud opening }} \\
\text { (days) }\end{array}$} & \multicolumn{2}{|c|}{$\begin{array}{c}\text { Number of tubers/ } \\
\text { plant }\end{array}$} & \multicolumn{2}{|c|}{$\begin{array}{l}\text { No. of days for } \\
\text { tuber maturity }\end{array}$} & \multicolumn{2}{|c|}{ Yield in $\mathrm{q} / \mathrm{ha}$} & \multicolumn{2}{|c|}{$\begin{array}{c}\text { Dry matter content } \\
(\%)\end{array}$} & \multirow{2}{*}{$\begin{array}{c}\begin{array}{c}\text { Light } \\
\text { blight }\end{array} \\
\text { damage } \\
\text { effect }\end{array}$} & \multirow{2}{*}{$\begin{array}{c}\begin{array}{c}\text { Contro } \\
\text { l }\end{array} \\
2016\end{array}$} \\
\hline & 2015-16 & 2016-17 & 2015-16 & 2016-17 & 2015-16 & 2016-17 & 2015-16 & 2016-17 & 2015-16 & 2016-17 & 2015-16 & 2016-17 & 2015-16 & 2016-17 & & \\
\hline E-4486 & 13.53 & 11.73 & 97.33 & 100.00 & 93.00 & 93.07 & 7.30 & 7.93 & 103.63 & 113.33 & 340.57 & 326.50 & 15.00 & 15.03 & ++ & ++ \\
\hline JI-5857 & 9.00 & 9.43 & 100.20 & 104.10 & 113.37 & 115.63 & 10.40 & 10.13 & 111.23 & 112.00 & 315.10 & 242.40 & 13.93 & 14.23 & ++ & ++ \\
\hline JI1804 & 9.99 & 9.83 & 97.13 & 99.71 & 112.23 & 112.77 & 10.37 & 10.37 & 104.33 & 100.33 & 349.77 & 255.77 & 14.57 & 14.63 & + & ++ \\
\hline JI1808 & 10.40 & 9.77 & 105.50 & 107.93 & 115.67 & 114.27 & 9.93 & 9.90 & 113.30 & 113.30 & 370.17 & 244.77 & 14.37 & 14.77 & + & + \\
\hline JG-224 & 9.63 & 9.97 & 107.13 & 105.13 & 113.23 & 116.67 & 13.73 & 12.90 & 112.40 & 112.10 & 413.90 & 258.57 & 14.93 & 15.30 & ++ & ++ \\
\hline JG-657 & 10.00 & 9.77 & 103.67 & 103.53 & 111.53 & 112.73 & 14.80 & 14.64 & 110.50 & 111.73 & 325.57 & 254.63 & 14.57 & 14.97 & +++ & +++ \\
\hline JE-808 & 9.43 & 9.53 & 100.03 & 100.13 & 103.27 & 104.83 & 15.27 & 14.83 & 103.51 & 100.43 & 322.93 & 308.83 & 14.50 & 14.73 & ++ & ++ \\
\hline JF-110 & 9.20 & 9.63 & 103.43 & 103.33 & 111.57 & 113.43 & 14.80 & 14.93 & 100.37 & 107.90 & 332.87 & 312.60 & 14.80 & 14.80 & +++ & +++ \\
\hline JF-27 & 10.67 & 10.10 & 102.90 & 103.13 & 110.07 & 114.00 & 14.40 & 14.80 & 104.33 & 100.20 & 324.00 & 311.07 & 14.47 & 16.00 & +++ & +++ \\
\hline JF-547 & 9.57 & 9.40 & 103.43 & 101.53 & 110.83 & 110.27 & 14.17 & 13.83 & 107.11 & 110.10 & 330.90 & 327.73 & 15.07 & 14.60 & ++ & ++ \\
\hline JG1334 & 9.80 & 9.20 & 100.00 & 99.53 & 105.60 & 107.27 & 13.93 & 14.60 & 114.57 & 109.17 & 318.17 & 316.37 & 14.37 & 13.87 & + & + \\
\hline FR/B-10 & 8.60 & 8.70 & 99.23 & 99.33 & 104.87 & 106.23 & 14.13 & 14.07 & 95.23 & 98.20 & 337.43 & 316.80 & 14.87 & 14.07 & +++ & +++ \\
\hline JH-222 & 7.60 & 7.00 & 93.11 & 93.47 & 99.90 & 101.03 & 14.50 & 13.83 & 99.53 & 93.93 & 350.40 & 331.99 & 13.73 & 13.80 & ++ & ++ \\
\hline EM/H-1601 & 8.47 & 7.63 & 100.41 & 100.70 & 104.23 & 104.00 & 14.40 & 13.68 & 107.33 & 100.93 & 309.27 & 328.90 & 14.57 & 14.67 & ++ & ++ \\
\hline JF-4864 & 9.40 & 8.90 & 101.70 & 100.10 & 115.07 & 119.33 & 14.50 & 13.83 & 103.03 & 107.00 & 187.43 & 218.73 & 14.70 & 14.00 & + & + \\
\hline JF-5106 & 9.47 & 9.04 & 110.23 & 107.21 & 117.50 & 120.30 & 14.60 & 13.23 & 114.50 & 114.27 & 289.40 & 244.93 & 14.23 & 14.57 & +++ & +++ \\
\hline JF-4915 & 8.80 & 8.53 & 107.51 & 105.73 & 116.63 & 110.47 & 12.03 & 12.70 & 112.63 & 112.17 & 290.17 & 217.43 & 14.03 & 14.77 & +++ & +++ \\
\hline JH-49 & 9.07 & 9.07 & 104.40 & 103.53 & 115.23 & 115.10 & 12.90 & 13.73 & 110.80 & 110.23 & 235.80 & 214.80 & 14.80 & 15.33 & +++ & ++ \\
\hline JH-516 & 10.07 & 10.63 & 104.53 & 100.21 & 115.50 & 115.47 & 14.37 & 13.77 & 113.27 & 114.30 & 248.17 & 248.40 & 15.10 & 15.17 & +++ & ++ \\
\hline JI-5871 & 10.47 & 9.73 & 107.27 & 100.77 & 114.27 & 115.13 & 14.80 & 13.90 & 114.67 & 114.60 & 267.63 & 219.60 & 14.53 & 14.73 & +++ & ++ \\
\hline FR-B-4 & 9.70 & 10.07 & 100.12 & 105.47 & 100.23 & 102.75 & 12.77 & 13.13 & 109.86 & 110.24 & 245.10 & 226.37 & 14.67 & 15.27 & +++ & ++ \\
\hline FR/B-21 & 9.50 & 9.40 & 104.53 & 106.18 & 104.86 & 105.13 & 13.57 & 13.63 & 110.25 & 110.86 & 232.50 & 214.47 & 15.63 & 15.23 & ++ & +++ \\
\hline FR/B-105 & 10.13 & 10.07 & 110.72 & 109.28 & 107.65 & 106.43 & 14.57 & 12.77 & 107.35 & 109.85 & 277.93 & 241.27 & 15.10 & 14.97 & ++ & ++ \\
\hline G-2524 & 9.57 & 10.83 & 107.36 & 110.76 & 110.29 & 109.74 & 10.80 & 11.00 & 95.27 & 98.61 & 240.43 & 239.97 & 14.90 & 15.07 & +++ & +++ \\
\hline K.Sheetman & 10.80 & 9.70 & 110.82 & 110.36 & 112.33 & 111.65 & 10.53 & 10.27 & 109.31 & 104.66 & 343.50 & 268.47 & 14.97 & 14.93 & + & + \\
\hline K. Chandramukhi & 9.80 & 9.90 & 103.63 & 101.46 & 115.25 & 113.19 & 9.83 & 10.40 & 103.63 & 104.34 & 375.57 & 284.20 & 15.10 & 14.53 & ++ & ++ \\
\hline K. Bahar & 11.10 & 11.13 & 102.35 & 105.26 & 110.76 & 109.28 & 11.07 & 11.07 & 112.35 & 112.48 & 336.47 & 245.38 & 14.80 & 15.00 & +++ & ++ \\
\hline K. Lalima & 12.00 & 13.37 & 104.51 & 106.83 & 107.65 & 110.62 & 11.40 & 10.90 & 110.22 & 110.78 & 363.47 & 241.70 & 15.30 & 15.07 & + & + \\
\hline K. Badshah & 12.10 & 11.20 & 107.45 & 103.28 & 108.74 & 109.73 & 10.73 & 10.20 & 112.65 & 112.31 & 345.47 & 239.27 & 15.83 & 15.73 & + & + \\
\hline K. Jyoti & 11.27 & 11.10 & 101.58 & 103.12 & 112.57 & 114.35 & 11.67 & 11.37 & 114.21 & 113.23 & 262.37 & 258.30 & 15.10 & 15.10 & ++ & ++ \\
\hline K. Alankar & 10.17 & 9.33 & 104.27 & 103.31 & 113.25 & 110.28 & 12.20 & 11.53 & 113.27 & 114.31 & 383.67 & 251.80 & 14.60 & 14.37 & +++ & ++ \\
\hline K. Sinduri & 10.40 & 11.10 & 105.62 & 103.86 & 110.43 & 109.87 & 15.57 & 15.70 & 110.67 & 112.54 & 345.73 & 259.80 & 15.23 & 15.47 & + & ++ \\
\hline C.D at $5 \%$ & 1.06 & 0.99 & 1.25 & 1.58 & 2.32 & 2.10 & 1.05 & 0.94 & 1.06 & 1.26 & 19.05 & 20.39 & 0.56 & 0.53 & & \\
\hline
\end{tabular}

(Late Blight Effect $=20-25 \%=+; 26-60 \%=++; 61-80 \%=+++)$ 
Different aspects were found to have positive role towards proper growth and development of potato crop. The effect of late blight was observed in treatments JI-1804, JI 1808, JG1334, JF-4864, K. Sheetman, K. Lalima, K. Jyoti and K. Sinduri in ranging from (2025\%) during 2015-16. The maximum damaging effect was recorded in +++ signs which was observed ranging from 61 to 80 per cent in the investigations during 2015-16. Similarly in second year the damaging effect was observed minimum in treatments JI 1808, JG-1334, JF-4864, K. Sheetman, K. Lalima and $\mathrm{K}$. Badshah where it was estimated as 20 to 25 per cent in the crop plants during 201617. It is also evident that the maximum damaging effect was observed in varying range as 61 to 80 per cent in JG-657, JG-110, JF-27, JF-5106, JF-4915, FR/B-21 and G2524 treatments in the year 2016-17. In regular visits it was observed that late blight was noted during the period of overnight duration as per the atmospheric temperature and humidity in the air in the locations.

It is concluded that important information on different aspects of seed tubers-sprouting, plant growth and development of parameters was gathered in all the treatments. All 32 varieties/strains/cultures grown in performance were found to express normal information for benefits of farmer. Findings of results were drawn on the basis of information gathered in observation recorded and data calculation for significance. Treatment JG-224, JH-222, FR/B-21, K. Chandramukhi, K. Lalima and K. Badshah were found promising. K. Badshah was found the best of all treatments and next best were K. Bahar, K. Alankar and K. Sunder's.

\section{References}

Accatino, P. and P. Malagamba (1982). Potato production from True Seed. Int. Potato Central Lime Peru, pp : 20.
Agrawal, A. and R.S. Tiwari (2004). Genetic variability in Garlic (Allium sativum L.). Indian J. Agri. Sci. 74 : 164-165.

Chaudhary, B. (1972). Vegetables. National Book Trust, India, pp : 95-103

Davis, H.T. (1969). The influence of stem thinning on tuber size. Amer. Potato J., $46: 287-290$.

Foxe, M.I. (1990). Production of virus tested seed potatoes in Ireland. Abst. Int. Sem. New Frontiers Hort., Bangalore, pp : 49. 70-84.

Gangiger, V.M. (1992). Use of growth retardants in potato (Solanum tuberosum L.) production. M.Sc. (Agri.) Thesis U.A.S. Dharwad.

Gupta, A. and M.C. Saxena (1976). Dry matter and nitrogen accumulation in different plant parts of potato in relation to soil fertility. Indian J. Agric. Sci., 46 : 41-45.

Hagry, P. and A. Fangmeler (2009). Atmospheric $\mathrm{CO}_{2}$ enrichment affects potatoes. Above ground biomass production and tuber yield. European $J$. Agron. 30 :

Kumar, J.S. (1972). Response of potato varieties to different planting dates under force condition. M.Sc. Thesis submitted to G.B.P.U.A. \& T., Pant Nagar, Nainital.

Leela, D., (1993). Present status and future scenario of weed control in Horticultural crops. Golden Jubilee Symposium Horticulture Research A Chaning Scenario. Bangalore (May, 2426).

Luthra, S.K., J. Gopal, V. Kumar, B.P. Singh and S.K. Pandey (2008). Evaluation of Potato Germplasm for frost tolerance. Indian J. Hort. 65 : 344-346.

Madalageri, B.B., R.M. Hosamani, R.D. Dharmalli and S. Kulkarni (1990). Germplasm evaluation for yield and disease resistance in potato. Abst. Int. Sem. New Frontiers Hort. held at 
Bangalore, pp : 191

Minhas, J.S., P. Kumar, D. Kumar, V.K. Dua and Y.K. Gupta (2018). Respone of potato to elevated $\mathrm{CO}_{2}$ under short days growth physiological parameters and tuber yield. 70 (1) : 82-86.

Mishra, S.S. (1996). Biology of important potato pests and their management. Training Course Potato Res. Methodol. AICPIP Sci., held at Shimla, pp : 110112.

Moorly, J. (1978). The physiology of growth and tuber yield. In Harris, P.M. ed. The potato crop. The scientific basis for improvement. London Chappman and Hall, pp : 153-194

Murlidharan, V.K. and N.A. Amalraj (1991). Potato on under utilized tuber for the tropics. Indian Hort., 36 (1) : 31-37.

Murlidharan, V.K. and N.A. Amalraj (1991). Potato on under utilized tuber for the tropics. Indian Hort., 36 (1) : 31-37.

Palkar, S.I. (1956). Age differences in content of phenotypic components and their distribution in the organs of potato plants. Deklody Akad Nauk SSAR IIT $P P$ : 1375-1377.

Pandita, M.L. (1971). A varietal evaluation and selection potato. Ann. Report H.A.U., Hissar : 42-44.

Pushkarnath (1964). Potato in India : varieties. Indian Council of Agricultural Research, New Delhi, pp : 493.

Pushkarnath (1964). Potato in India : varieties. Indian Council of Agricultural Research, New Delhi, pp : 493.

Rai, M. and D.C. Dhankar (1988). Effect of zinc application and mulching on potato production mid upland of Tripura. Lalbagh J. Mysore. 18 : 15-18.

Singh, K. (1959). Quality in potato, Kanpur. Agric. Coll. J., 28 (1-2) : 31-34.

Singh, R.P., V.P. Pandey and H.N. Tatoo (1985). Studies on the performance of potato varieties in Tarai. Ann. Report. G.B. Pan Univ. of Agric. \& Tech., Pantnagar, Nainital, pp : 181-183.

Tiwari, D.K. and J.P. Tiwari (1975). Ecophysiological adoptability of new potato varieties at Jabalpur. Rez. J., 9 : 44-49.

Tiwari, D.K. and J.P. Tiwari (1975). Ecophysiological adoptability of new potato varieties at Jabalpur. Rez. J., 9 : 44-49.

\section{How to cite this article:}

Mishra. T. S., H. M. Singh, Abhimanyu Chaturvedi and Mishra U. S. 2020. Studies on Comparative Behaviour of Performance Leading to Yield and integrated Management of Late Blight Disease of Potato in Allahabad Agro-Climate Condition. Int.J.Curr.Microbiol.App.Sci. 9(06): 578-585. doi: https://doi.org/10.20546/ijcmas.2020.906.075 